\title{
| Clinical features and prognostic value of functional disorders and pulmonary comorbidity in adult patients prior to allogeneic hematopoietic stem cell transplantation
}

\begin{abstract}
Egor A. Kulagin ${ }^{1}$, Alisa G. Volkova ${ }^{2}$, Ilya Yu. Nikolaev ${ }^{2}$, Oleg V. Goloshchapov ${ }^{2}$, Anna G. Smirnova ${ }^{2}$, Tatiana A. Rudakova ${ }^{2}$, Elena I. Darskaya ${ }^{2}$, Elena V. Morozova ${ }^{2}$, Nataliya B. Mikhaylova ${ }^{2}$, Julia D. Rabik ${ }^{3}$, Victoria G. Timchik ${ }^{3}$, Tatiana I. Shchemelinina ${ }^{3}$, Ruf D. Skvortsova ${ }^{3}$, Tatiana S. Razumovskaya ${ }^{3}$, Sergey N. Bondarenko ${ }^{2}$, Ivan S. Moiseev ${ }^{2}$, Valeriy N. Marchenko ${ }^{1}$, Vasiliy I. Trofimov ${ }^{1}$, Boris V. Afanasyev ${ }^{2}$

${ }^{1}$ M. Chernorutskiy Department of Hospital Therapy, Pavlov First Saint Petersburg State Medical University, St. Petersburg, Russia ${ }^{2}$ Raisa Gorbacheva Memorial Research Institute of Pediatric Oncology, Hematology and Transplantation, Pavlov First Saint Petersburg State Medical University, St. Petersburg, Russia

${ }^{3}$ Department of Functional Diagnostics №2, Pavlov First Saint Petersburg State Medical University, St. Petersburg, Russia
\end{abstract}

Dr. Egor A. Kulagin, M. Chernorutskiy Department of Hospital Therapy, Pavlov First Saint Petersburg State Medical University, L. Tolstoy St 6-8, 197022, St. Petersburg, Russia
Phone: +7 (812) 3386746

E-mail: egor.kulagin.spb@gmail.com

Citation: Kulagin EA, Volkova AG, Nikolaev I.Yu et al. Clinical features and prognostic value of functional disorders and pulmonary comorbidity in adult patients prior to allogeneic hematopoietic stem cell transplantation. Cell Ther Transplant 2019; 8(2): 26-37.

\section{Summary}

High efficacy of allogeneic hematopoietic stem cell transplantation (allo-HSCT) in a wide range of malignant and non-malignant hematopoietic disorders system is limited to the risk of serious complications and non-relapse mortality (NRM). Pre-existing comorbidities before allo-HSCT are among key factors for NRM.

The purpose of this study was to characterize the potential pre-transplant factors of pulmonary comorbidity and integral indicators of pulmonary function tests (PFT) and to evaluate their prognostic value for the alloHSCT outcomes in adult patients.

\section{Patients and methods}

The study included 355 patients, among them 149 (42\%) in the prospective phase of the study. The cohort included patients with acute leukemia (60\%), myeloproliferative diseases (10\%), myelodysplastic syndrome (5\%), lymphomas (17\%), and severe aplastic anemia (8\%). The median age at the time of allo-HSCT was 33 years old (18 to 66). We analyzed all the factors that could affect lung function before allo-HSCT. The severity of pulmonary comorbidity was assessed on the basis of forced expiratory volume in one second (FEV1) and diffusing capacity of carbon monoxide (CO) (DLco), in accordance with the criteria of the Hematopoietic Cell Transplantation Specific Comorbidity Index (HCT-CI). The prognostic value of pulmonary comorbidity was investigated with respect to the cumulative incidence of mechanical ventilation (MV) and NRM rates.

\section{Results}

Tobacco smoking (32\%), history of chronic obstructive pulmonary disease (COPD) and bronchial asthma (BA) (5\%), previous pulmonary infections (45\%), potentially pulmonary toxic chemotherapy (79\%), previous autoHSCT (8\%), usage of immune checkpoint inhibitors (5\%), mediastinal radiation therapy $(6 \%)$ were the most common pulmonary compromising factors before alloHSCT. According to the HCT-CI criteria, 90 patients (25\%) had low FEV1 values, with $14 \%, 9 \%$ and $2 \%$ of mild, moderate and severe grade respectively. DLco disorders were diagnosed in $69 \%$ of the patients examined, including $29 \%, 28 \%$, and $12 \%$ of mild, moderate, and 
severe grade respectively. Cumulative incidence of $\mathrm{MV}$ within 100 days after allo-HSCT was $7.2 \%, 10.9 \%, 16.7 \%$, and $22.1 \%$ in patients with pulmonary comorbidity of 0 , 1, 2, 3 degrees, respectively. The degree of pulmonary comorbidity was an independent risk factor for NRM (hazard ratio 1.39; CI 95\%; 1.03-1.89; $\mathrm{p}=0.033$ ), being associated with a decrease in overall survival (OS).

\section{Conclusions}

Adult patients have a wide range of pulmonary comorbidity factors before allo-HSCT. HCT-CI pulmonary comorbidity is an independent risk factor for MV during the first 100 days after allo-HSCT and NRM.

\section{Keywords}

Allogeneic hematopoietic stem cell transplantation, adults, pulmonary comorbidity, pulmonary functional tests, clinical prognosis.

\section{Introduction}

Allogeneic hematopoietic stem cell transplantation (alloHSCT) is the standard treatment option in a significant proportion of patients suffering from malignant (acute and chronic leukemias, lymphomas, primary myelofibrosis, myelodysplastic syndrome, etc.) and non-malignant blood diseases (aplastic anemia, primary immunodeficiency, inherited metabolic disorders, hemoglobinopathies, etc.) [1-4]. Despite high therapeutic efficacy, allo-HSCT is associated with the risk of disability and death caused by various post-transplant complications such as graft-versus-host disease (GVHD), severe organ toxicity, infections, and worsening of concomitant diseases causing nonrelapse mortality (NRM). Careful donor selection, flexible conditioning regimens, using of novel strategies for GVHD prevention and prophylaxis of infectious complications reduce the risk of the allo-HSCT procedure $[5,6]$. Nevertheless, the problem of NRM remains relevant what determines the need to evaluate all potential pre-transplant risk factors associated with both the underlying disease and its treatment, as well as with comorbid conditions.

In 1987 M. Charlson proposed a comorbidity index, in order to stratify the risk of post-transplant complications. The Charlson Comorbidity Index (CCI) was being used for a long time, but it had several significant limitations and low sensitivity [7]. In 2005, M. Sorror and colleagues modified the CCI and proposed the first specific Hematopoietic Cell Transplantation Comorbidity Index (HCT-CI) which was amended in 2014 [8, 9]. HCT-CI differed from CCI, e.g., in grading the severity of pulmonary comorbidities by introducing specific parameters of pulmonary function test (PFT), i.e., forced expiratory volume in one second (FEV1) and diffusing capacity of carbon monoxide (CO) (DLco). The Fred Hutchinson Cancer Research Center study demonstrated high prognostic significance of these PFT parameters in relation to the risk of severe respiratory failure development and mortality within the first 120 days after HSCT [10]. Importantly, the described cohort consisted by $95 \%$ of patients given myeloablative conditioning (MAC). At the same time, in a number of studies using reduced intensity conditioning (RIC), the total lung capacity (TLC) and the forced vital capacity (FVC) had a more prognostic significance rather than FEV1 and DLco parameters [11].
The evolving concept of evaluating comorbidities during HSCT is to identify subclinical organ dysfunctions, which cannot be evaluated by means of HCT-CI index. The most progress in this area has been reached in evaluation and prediction of acute kidney injury and cardiotoxicity using highly sensitive biomarkers $[12,13]$. However, currently there are not such biomarkers for detection of subclinical lung injury in the context of HSCT [14].

The frequency of detection and prognostic significance of abnormal pulmonary functional tests (PFT) during HSCT was significantly increased due to implication of novel diagnostic criteria. In the original retrospective study of M. Sorror et al., among 347 patients with moderate or high severity of pulmonary comorbidity, 122 patients died without signs of relapse, including $24 \%$ of deaths directly from the toxic lung injury [9].

Currently, all potential allo-HSCT recipients are undergoing PFTs. However, the pre-transplant examination in real clinical practice is limited to the screening level, often with incorrect spirometry manoeuvres, and the data are interpreted without taking into account all the potential factors that compromise pulmonary health before allo-HSCT procedure. Previous pulmonary infections, an extremely wide range of medical drugs are able to induce pulmonary toxicity, history of mediastinal radiation therapy, lung involvement due to underlying diseases, and other factors, along with chronic obstructive pulmonary disease (COPD) and bronchial asthma (BA) are of importance in the risk of post-transplantation pulmonary complications and NRM. At the same time, a novel unexplored landscape of pulmonary comorbidity is being observed in the context of expanding indications for allo-HSCT, new treatment modalities before allo-HSCT, increasing age limit for recipients, widespread usage of non-myeloablative conditioning and GVHD prophylaxis based on post-transplant cyclophosphamide.

Hence, the aim of our work was to perform a comprehensive evaluation of all potential pre-transplant factors of lung injury and integral PFT data in a large cohort of adult allo-HSCT patients suffering from malignant and non-malignant blood diseases. 


\section{Patients and methods}

The present study was carried out at the Raisa Gorbacheva Memorial Research Institute for Pediatric Oncology, Hematology and Transplantation, M. Chernorutskiy Department of Hospital Therapy, and Department of Functional Diagnostics № 2 at Scientific and Clinical Research Center of the Fist St. Petersburg State I. Pavlov Medical University. The study was approved by the local ethics committee. All the patients gave written informed consent.

The study was both retrospective (data analysis until December 31, 2017) and prospective (data analysis after January 1, 2017). The analysis included patients with various malignant and non-malignant blood diseases who underwent allo-HSCT (in retrospective phase) or were scheduled for it (in prospective phase). The inclusion criteria for the study were as follows: 1. Patients' age at the time of allo-HSCT over 18 years old; 2 . Availability of sufficient anamnestic data about previous respiratory diseases, or risk factors for bronchopulmonary system; 3. Presence of pre-transplant PFT results.

The study was based on real clinical practice, so it was not limited by the characteristics of the donor (HLA-matched sibling, unrelated, haploidentical), graft source (bone marrow, peripheral blood), conditioning regimen (MAC, RIC), and regimen of GVHD prophylaxis.

Identification of pre-transplant risk factors for lung injury was based on a detailed history taking and analysis of available medical records (case histories, outpatient records, etc.). Pulmonary symptoms within one month before the start of conditioning (shortness of breath, cough, etc.), history of BA, COPD, previous pulmonary infections, administration of drugs causing potential pulmonary toxicity (bleomycin, carmustine, cytosine arabinoside, methotrexate) and immune checkpoint inhibitors (nivolumab, pembrolizumab), previous mediastinal radiation therapy, proven or suspected specific lung involvement and the status of the underlying blood disease at the moment of allo-HSCT were documented.

The data analysis included results of PFTs performed within 4 weeks before the allo-HSCT procedure. PFTs included spirometry and DLco measurement. All the PFTs were performed with MasterScreen equipment (CareFusion 234 $\mathrm{GmbH}$, Erich Jaeger, Höchberg, Germany) according to the standards of the American Thoracic Society and European Respiratory Society (ATS/ERS) [15]. DLco measurement was performed with single-breath hold technique, using a gas mixture consisting of CO (0.25-0.30\%), helium (8.9-10.0\%) and synthetic air. DLco value was adjusted for hemoglobin concentration at the time of PFTs performance [16, 17]. The analyzed PFT parameters included spirometric vital capacity (VC), FVC, FEV1, FEV1/VC ratio (Tiffeneau index), DLco (adjusted for hemoglobin concentration), alveolar volume (Va), carbon monoxide transfer coefficient (Krogh factor, Kco). The absolute values of the PFT parameters and their percentage to predicted values were evaluated using formulas for predicted PFT values by R. Clement et al. [18].

Severity of pulmonary comorbidity was evaluated according to criteria of HCT-CI $[8,9]$. Mild pulmonary comorbidity was defined as DLco and/or FEV1 values of $81 \%-90 \%$, or dyspnea at moderate physical activity. Moderate pulmonary comorbidity was defined as DLco and/or FEV1 values of $66 \%-80 \%$, or dyspnea at minimal activity. Severe pulmonary comorbidity was defined as DLco and/or FEV1 values of $\leq 65 \%$ or dyspnea at rest, or requirement for oxygen therapy.

Statistical evaluation of the cohort and outcomes of alloHSCT was performed as of May 1, 2019. Descriptive characteristics included the number of observations and proportions for discrete factors, medianes, range of values, interquartile ranges and 95\% confidence intervals (CI) for continuous values. Differences between the analyzed groups were evaluated using Kruskal-Wallis test (quantitative characteristics), Fisher's exact test and Pearson chi-square (categorical characteristics).

The cumulative incidence of mechanical ventilation (MV) and NRM rates were calculated from the date of allo-HSCT to the date of the beginning of the MV and death unrelated to the relapse of the underlying disease, respectively. Death prior to the onset of mechanical ventilation and relapses were considered competing risks. Prognostic value of the severity of pulmonary comorbidity and other potential risk factors for NRM (age, diagnosis, disease status at the time of HSCT, type of donor, protocol of GVHD prophylaxis, year of HSCT, severe acute GVHD) was performed in the FineGray regression model for competing events. Overall survival (OS) was estimated using the Kaplan-Meier method from the date of allo-HSCT to the date of death, or the last contact with the patient. Comparison of survival was performed using the log-rank test.

The two-sided alternative testing hypothesis was applied, being statistically significant at the p-value of $<0.05$. Statistical analysis was performed using EZR statistical software, version 2.15.2 (R Foundation for Statistical Computing, Vienna, Austria).

\section{Results}

\section{Clinical characteristics}

As of May 1, 2019, 355 patients were included in the study, among them 206 (58\%) and 149 (42\%) in the retrospective and prospective phases, respectively. The basic demographic and clinical characteristics of the patient cohort are presented in Table 1.

In terms of age, gender, diagnosis and clinical indications for allo-HSCT, donor characteristics, conditioning regimens, the analyzed cohort appears to be representative and generally reflects the current transplant activity in adult patients.

\section{Baseline factors of pulmonary comorbidity}

At the first stage of the study, we analyzed the baseline potential risk factors and causes of pulmonary comorbidity in the entire patient cohort, as listed in Table 2 .

Tobacco smoking, including high pack-year rates $(>20)$ for every fourth smoker was most frequent (32\%) among the basic risk factors unrelated to the underlying disease and its treatment. A documented diagnosis of COPD and BA was present in, respectively, $15(4.2 \%)$ and $4(1.1 \%)$ of HSCT 
Table 1. The basic demographic and clinical characteristics of patient cohort

\begin{tabular}{|l|l|}
\hline Characteristics & Value \\
\hline Total number of patients, $n$ (\%) & $355(100)$ \\
\hline Age, years, median (range) & $33(18-66)$ \\
\hline Gender, $n$ (\%) & $186(52)$ \\
Male & $169(48)$ \\
Female & \\
\hline Diagnosis, n (\%) & $27(8)$ \\
SAA & $136(38)$ \\
AML & $79(22)$ \\
ALL & $22(6)$ \\
CML & $19(5)$ \\
MDS & $13(4)$ \\
MPD & $59(17)$ \\
\hline Lymphomas & $475(15-6972)$ \\
\hline Time from diagnosis to HSCT, days, median (range) & \\
\hline Donors, $n$ (\%) & $74(21)$ \\
HLA-matched sibling & $246(69)$ \\
Unrelated & $35(10)$ \\
\hline Haploidentical & \\
\hline Conditioning regimens, $n$ (\%) & $141(40)$ \\
MAC & $214(60)$ \\
RIC & \\
\hline Graft source, $n$ (\%) & $133(38)$ \\
BM & $218(61)$ \\
G-PBMC & $4(1)$ \\
BM and G-PBMC & \\
\hline
\end{tabular}

Abbreviations: SAA, severe aplastic anemia; AML, acute myeloid leukemia; $A L L$, acute lymphoblastic leukemia; $C M L$, chronic myeloid leukemia; MDS, myelodysplastic syndrome; MPD, myeloproliferative disease; MAC, myeloablative conditioning; RIC, reduced intensity conditioning; BM, bone marrow; G-PBMC, peripheral blood mononuclear cells mobilized by the granulocyte colony-stimulating factor

Table 2. Risk factors for pulmonary comorbidity

\begin{tabular}{|l|l|}
\hline Factors & Value \\
\hline Number of patients, $\mathrm{n}(\%)$ & $355(100)$ \\
\hline Tobacco smoking, $\mathrm{n}(\%)$ & $115(32.4)$ \\
\hline Smoking index (pack-year), $\mathrm{n}(\%)$ & \\
$<20$ & $86(75)$ \\
$\geq 20$ & $29(25)$ \\
\hline COPD, $\mathrm{n}(\%)$ & $15(4.2)$ \\
\hline BA, $\mathrm{n}(\%)$ & $4(1.1)$ \\
\hline Pulmonary infections before HSCT, $\mathrm{n}(\%)$ & $159(44.9)$ \\
Clinically documented pneumonia & $127(35.8)$ \\
Invasive mycosis & $57(16.1)$ \\
\hline Tuberculosis & $10(2.8)$ \\
\hline Potential pulmonary toxic chemotherapy, $\mathrm{n}(\%)$ & \\
Cytarabine & $230(64.9)$ \\
Bleomycin +/- cytarabine & $29(8.2)$ \\
\hline Carmustine & $19(5.4)$ \\
\hline Autologous HSCT, $\mathrm{n}$ (\%) & $30(8.5)$ \\
\hline Mediastinal radiotherapy, $\mathrm{n}$ (\%) & $22(6.2)$ \\
\hline Treatment with immune checkpoint inhibitors, $\mathrm{n}(\%)$ & $19(5.4)$ \\
\hline
\end{tabular}

Abbreviations: $C O P D$, chronic obstructive pulmonary disease; $B A$, bronchial asthma 
recipients. It should be noted that the majority of COPD patients (13/15) had a mild-severity disease, and intermittent BA was diagnosed in all 4 cases. The leading group of lung diseases reported before allo-HSCT was presented by pulmonary infections $(44.9 \%)$, dominated by clinically proven pneumonia (35.8\%). In general, microbiological verification of the pathogens in available medical documentation was low, and to a greater extent concerned only invasive mycoses with lung involvement (16\%). Ten patients $(2.8 \%)$ had the history of pulmonary tuberculosis, or radiological signs of previous tuberculosis which required secondary prophylaxis with tuberculostatic drugs.

Frequently used medical drugs with known lung toxicity, e.g., cytarabine (65\%), as well as bleomycin (8.2\%) and carmustine $(5.2 \%)$ applied in anticancer chemotherapy before allo-HSCT were also identified as potential risk factors. In addition, $30(8.5 \%)$ and $22(6.2 \%)$ patients had the history of high-dose chemotherapy followed by autologous HSCT and mediastinal therapeutic irradiation, respectively. Use of immune checkpoint inhibitors was considered another particular potential risk factor of pre-HSCT pulmonary injury (5.4\% of entire cohort).

In general, statistical evaluation of the potential factors predisposing for pulmonary compromise allowed us to identify two of the most characteristic disease-specific profiles associated with clinical course of the underlying disease and its treatment. The greatest number of risk factors for pulmonary comorbidity was revealed among the patients with lymphomas who received treatment with bleomycin, carmustine, cytarabine, immune checkpoint inhibitors, radiation therapy and autologous HSCT. The second group was represented by patients with acute leukemia and a part of MDS patients who received chemotherapy with cytarabine and showed high incidence of neutropenic pulmonary infections before allo-HSCT. Patients with AA did not exhibit specific drug pulmonary toxicity in anamnesis. However, this group of patients had an increased risk of iron overload, having been associated with multiple blood transfusions.

The proportion of smokers was higher among the patients with lymphomas (41\%) and myeloproliferative diseases, and MDS (39\%) compared with acute leukemia (30\%) and, especially, AA group (19\%). However, $48 \%$ of smokers with MPD and MDS had a smoking index of more than 20 packyears, which was significantly higher than for with acute leukemia $(22 \%)$ and lymphoma patients $(21 \%)(p=0.0461)$. The frequency of concomitant COPD was significantly higher among patients with MPD and MDS, i.e., 7/54 (13\%), compared with $0 / 27(0 \%), 5 / 215(2 \%)$ and $3 / 59(5 \%)$ with AA, acute leukemia and lymphomas respectively $(\mathrm{p}=0.0038)$.

These patterns are partly explained by differences in the age and the duration of the disease at the time of allo-HSCT. The median age was $28,32,37$ and 45 years in patients with SAA, acute leukemia, lymphomas and MPD and MDS respectively $(\mathrm{p}<0.0001)$. Accordingly, the median time between the diagnosis and allo-HSCT was 1.9, 1.1, 3.6, and 1.4 years $(\mathrm{p}<0.0001)$.

Chest computed tomography (CT) findings at the time of allo-HSCT were available in 270 (76\%) patients. Pathological changes in lung structures were documented in 190 (70.6\%) of the examined patients (Table 3 ). The signs of local pulmonary fibrosis and focal changes were the most frequent CT symptoms detected in more than $50 \%$ and $30 \%$ of patients, respectively.

\section{Table 3. Frequency of individual pulmonary CT symptoms before allo-HSCT $(n=270)$}

\begin{tabular}{|l|l|}
\hline CT symptoms & $\mathrm{n}(\%)$ \\
\hline Signs of local pulmonary fibrosis & $156(57.8)$ \\
\hline Focal changes & $105(38.9)$ \\
\hline Bronchial wall thickening & $52(19.3)$ \\
\hline Lymphadenopathy & $33(12.2)$ \\
\hline Ground glass opacity & $19(7.0)$ \\
\hline Infiltration (alveolar consolidation) & $18(6.7)$ \\
\hline Bronchiectasis/bronchioloectasis & $11(4.1)$ \\
\hline Bullae & $11(4.1)$ \\
\hline Terminal bronchiolitis (tree in bud) & $9(3.3)$ \\
\hline Emphysema & $9(3.3)$ \\
\hline Pleural effusion & $7(2.6)$ \\
\hline Mosaic pattern/expiratory air trapping & $6(2.2)$ \\
\hline Atelectasis & $6(2.2)$ \\
\hline Cavity/destruction & $4(1.5)$ \\
\hline Pneumothorax/pneumomediastinum & $0(0)$ \\
\hline
\end{tabular}

\section{Pulmonary function tests (PFT)}

At the next step of our study, we analyzed data from a preHSCT PFT with a focus on the key FEV1 and DLco parameters which are included in HCT-CI comorbidity criteria. Testing of FEV1 and other standard spirometry parameters covered the entire cohort $(n=355)$, while the data on the pulmonary diffusing capacity, including DLco were obtained from 76 patients, predominantly in the prospective phase of the study. The main parameters of spirometry and pulmonary diffusing capacity are presented in Table 4.

FEV1 varied within $49-145 \%$ of predicted, the median was $100.6 \%$, the interquartile range was $90-109.6 \%$. According to HCT-CI criteria, 90 (25\%) patients had low FEV1 value, including $14 \%, 9 \%$ and $2 \%$ of mild, moderate and severe grade respectively.

When verifying alterations of the pulmonary diffusing capacity, two methods were used to adjust the obtained DLco values for the hemoglobin levels. The median hemoglobin level at the time of DLco testing was $10.3 \mathrm{~g} / \mathrm{dL}$ (5.8-16.4). There was decreased hemoglobin level in $80 \%$ of women and $57 \%$ of men. Frequency of diffusion disorders by the DLco values seems to be definitely overestimated (96\%) when using the Cotes hemoglobin correction method, which is routinely recommended by ATS/ERS experts and used by default in pulmonary practice. The Dinakara method aiming to adjust DLco for hemoglobin levels provided a more accurate assessment and showed DLco disorders in $69 \%$ of the examined patients, including $29 \%, 28 \%$ and $12 \%$ 
frequency rates for mild-, moderate- and severe-grade alterations respectively.

When analyzing PFT data in patients with different diagnoses, more frequent bronchial obstruction according to the FEV1/VC parameter was found in the patients with MPD and MDS, whereas disorders of pulmonary diffusing capacity according to the adjusted DLco were more pronounced in patients with lymphomas (Table 5). Other tested parameters did not show significant dependence on the underlying disease.
In general, taking into account the maximum contribution of FEV1 or DLco data 68 (19\%), 49 (14\%) and 14 (4\%) patients corresponded to the criteria for mild, moderate and severe pulmonary comorbidity, respectively (Table 6).

\section{Prognostic value of pulmonary comorbidity for the outcome of allo-HSCT}

The prognostic value of pulmonary comorbidity parameters was tested by its analyzing against cumulative incidence of NRM and overall survival (OS) after allo-HSCT. In the

Table 4. Pulmonary function tests characteristics before allo-HSCT

\begin{tabular}{|l|l|l|l|l|l|l|}
\hline \multirow{2}{*}{ Parameter } & \multirow{2}{*}{$\mathbf{n}$} & \multirow{2}{*}{ Median } & \multicolumn{2}{|l|}{ Range } & \multicolumn{3}{l|}{ Quartile } \\
\cline { 4 - 7 } & & & Min & Max & Lower & Upper \\
\hline VC, \% pred. & 355 & 99.9 & 39.0 & 157.0 & 90.1 & 110.0 \\
\hline FVC, \% pred. & 355 & 99.2 & 44.4 & 147.0 & 90.4 & 108.6 \\
\hline FEV1, \% pred. & 355 & 100.6 & 49.0 & 145.0 & 90.0 & 109.6 \\
\hline FEV1/VC, \% & 355 & 83.0 & 55.8 & 166.8 & 75.8 & 89.4 \\
\hline FEV1/VC, \% pred. & 355 & 100.0 & 71.3 & 196.0 & 93.7 & 106.8 \\
\hline aDLco (Cotes), \% pred. & 76 & 64.6 & 39.8 & 107.1 & 54.4 & 79.2 \\
\hline aDLco (Dinakara), \% pred. & 76 & 84.2 & 51.1 & 130.0 & 72.4 & 94.4 \\
\hline Va, \% pred. & 76 & 93.1 & 60.5 & 130.5 & 85.5 & 102.6 \\
\hline Kco (Cotes), \% pred. & 76 & 69.2 & 42.9 & 102.7 & 59.2 & 78.1 \\
\hline Kco (Dinakara), \% pred. & 76 & 89.7 & 60.0 & 147.7 & 78.3 & 99.3 \\
\hline
\end{tabular}

Abbreviations: VC, vital capacity; FVC, forced vital capacity; FEV1, forced expiratory volume in one second; aDLco, adjusted for hemoglobin diffusing capacity for carbon monoxide; Va, alveolar volume; Kco, transfer coefficient of the lungs (i.e. DLco/Va), $\%$ pred., percentage of predicted value

Table 5. Pulmonary function tests before allo-HSCT according to the diagnosis

\begin{tabular}{|l|l|l|l|l|l|}
\hline Parameter & SAA & AML and ALL & Lymphomas & MPD and MDS & $\mathbf{p}$ \\
\hline $\mathbf{n}$ & 27 & 215 & 59 & 54 & NA \\
\hline VC, \% pred. & 100.0 & 100.0 & 98.2 & 97.1 & 0.3888 \\
& $(56.9-121.2)$ & $(48.0-157.0)$ & $(39.0-133.1)$ & $(61.0-134.2)$ & \\
\hline FVC, \% pred. & 99.4 & 98.9 & 101.0 & 101.6 & 0.9435 \\
& $(57.0-115.5)$ & $(68.0-147.0)$ & $(44.4-138.0)$ & $(65.0-129.8)$ & \\
\hline FEVI, \% pred. & 104.0 & 100.7 & 99.0 & 97.3 & 0.2112 \\
& $(74.0-130.0)$ & $(59.0-145.0)$ & $(49.0-140.0)$ & $(72.0-131.2)$ & \\
\hline FEV1/VC, \% & 86.8 & 83.0 & 82.9 & 79.1 & 0.0141 \\
& $(73.5-135.4)$ & $(55.8-166.8)$ & $(63.2-138.8)$ & $(60.6-129.2)$ & \\
\hline FEV1/VC, \% pred. & 103.2 & 100.0 & 102.9 & 98.6 & 0.1273 \\
& $(83.0-166.3)$ & $(71.3-196.0)$ & $(76.2-173.2)$ & $(78.7-167.2)$ & \\
\hline aDLco (Cotes), \% pred. & 58.8 & 65.5 & 58.7 & 68.6 & 0.8884 \\
& $(52.2-79.6)$ & $(39.8-107.1)$ & $(47.5-91.4)$ & $(41.8-96.2)$ & \\
\hline aDLco (Dinakara), \% pred. & 87.6 & 85.8 & 67.7 & 83.1 & 0.0438 \\
& $(73.9-104.0)$ & $(51.1-130.0)$ & $(56.9-91.8)$ & $(66.7-122.3)$ & \\
\hline Va, \% pred. & 94.0 & 93.2 & 89.0 & 94.6 & 0.4017 \\
& $(64.4-109.8)$ & $(71.5-130.5)$ & $(60.5-97.0)$ & $(80.4-113.3)$ & \\
\hline Kco (Cotes), \% pred. & 64.0 & 67.7 & 70.5 & 71.5 & 0.6990 \\
& $(50.7-77.2)$ & $(42.9-96.7)$ & $(50.2-102.7)$ & $(50.4-101.9)$ & \\
\hline Kco (Dinakara), \% pred. & 96.3 & 89.3 & 73.5 & 90.7 & 0.3439 \\
& $(70.3-147.7)$ & $(63.6-108.1)$ & $(60.0-106.5)$ & $(69.5-129.3)$ & \\
\hline
\end{tabular}

Note: for abbreviations, see Table 1 and Table 4. 
Table 6. Severity of pulmonary function abnormalities before allo-HSCT

\begin{tabular}{|l|l|l|l|}
\hline HCT-Cl criteria & $\begin{array}{l}\text { FEV1 } \\
\text { n (\%) }\end{array}$ & $\begin{array}{l}\text { aDLco (Dinakara) } \\
\mathbf{n}(\%)\end{array}$ & $\begin{array}{l}\text { Maximal score } \\
\mathbf{n}(\%)\end{array}$ \\
\hline Normal $(>90 \%)$ & $265(75)$ & $24(31)$ & $224(63)$ \\
\hline Mild $(81-90 \%)$ & $52(14)$ & $22(29)$ & $68(19)$ \\
\hline Moderate (66-80\%) & $32(9)$ & $21(28)$ & $49(14)$ \\
\hline Severe $(\leq 65 \%)$ & $6(2)$ & $9(12)$ & $14(4)$ \\
\hline
\end{tabular}

Note: for abbreviations see Table 4; HCT-CI, hematopoietic cell transplantation specific comorbidity index.

whole cohort, NRM and cumulative incidence of relapse in 2 years were $21.0 \%$ (95\% CI, 16.4-25.9) and 10.5\% (95\% CI, 7.3-14.3).

Stratification of patients according to the severity of pulmonary comorbidity revealed significant differences in NRM (Fig. 1). The cumulative incidence of death without signs of relapse of the underlying disease within 12 months after allo-HSCT was $13.8 \%$ (CI 95\%, 9.5-18.9), 14.1\% (CI 95\%, 6.4-24.7), 26.7\% (CI 95\%, 14.5-40.4) and 53.2\% (CI 95\%, 22.1-76.9) with pulmonary comorbidity $0,1,2,3$ degrees respectively $(\mathrm{p}=0.0004)$.

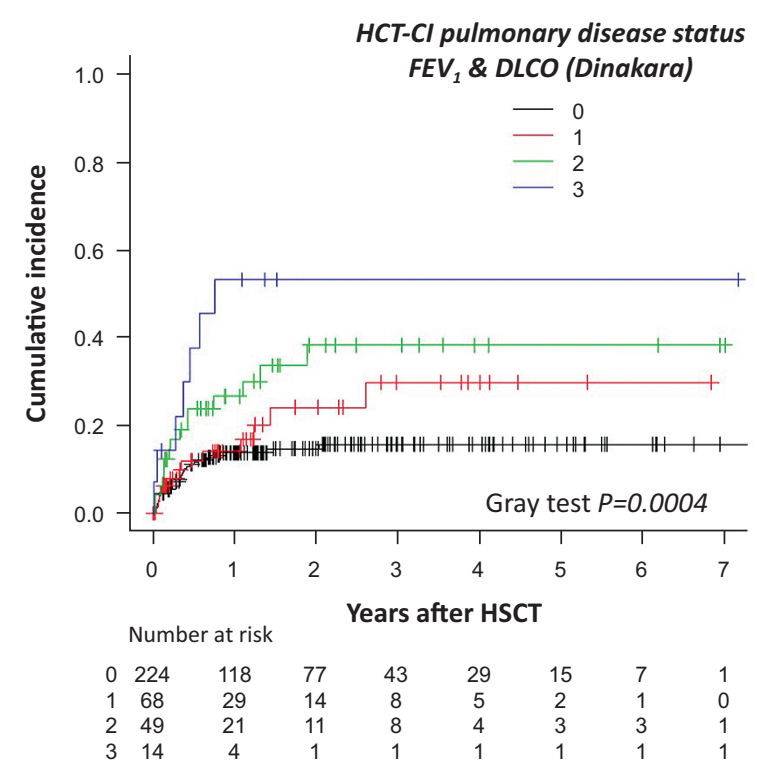

Figure 1. NRM with stratification of patients according to the severity of pulmonary comorbidity

The value of pulmonary comorbidity was further evaluated by a surrogate criterion of severe respiratory failure with need for mechanical ventilation (MV). Indications for MV occurred in 34 (9.6\%) and 54 (15.2\%) patients during the first 100 days and 1 year after allo-HSCT, respectively. In two other cases, MV was performed later. In order to reduce the significance of the primary disease relapse, further analysis was carried out for patients who developed severe respiratory failure during the first 100 days after allo-HSCT.

Stratification of patients according to the pulmonary comorbidity revealed a significant increased risk of switching to MV in high-risk patients (Fig. 2). Cumulative incidence of the MV within 100 days from allo-HSCT was 7.2\% (CI 95\%,
3.8-10.6), 10.9\% (CI 95\%, 2.9-18.2), 16.7\% (CI 95\%, 5.426.6) and $22.1 \%$ (CI 95\%, 0-41.3) in patients with pulmonary comorbidity of $0,1,2$ and 3 degree, respectively $(\mathrm{p}=0.0176)$.

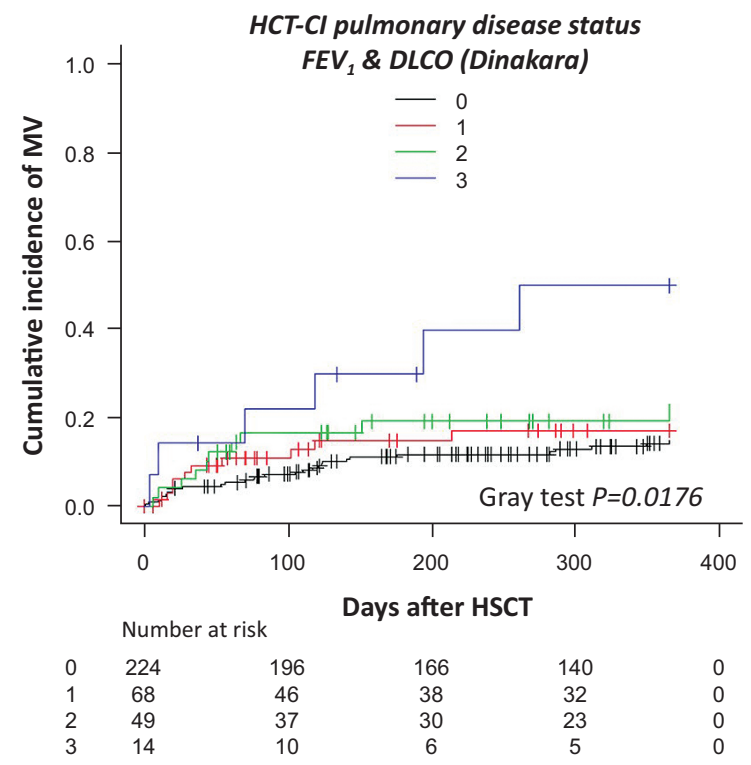

Figure 2. Cumulative incidence of mechanical ventilation with stratification of patients according to the severity of pulmonary comorbidity

Prognostic significance of the degree of pulmonary comorbidity for the risk of NRM was confirmed in a multivariate analysis, using the Fine-Gray regression model for competing events (Table 7). Other factors associated with increased risk of NRM were: primary diagnosis (maximum risk for MPD and MDS, minimum for SAA), lack of remission at the time of allo-HSCT, MAC regimen, type of donor (maximum risk for a haploidentical donor), year of HSCT and the presence of severe acute GVHD (aGVHD).

In contrast to the severity of PFT disorders, none of the potential pulmonary comorbidity factors discussed above (smoking, presence of lung diseases before HSCT, pulmonary toxicity, radiation therapy), as well as the age of patients at the time of allo-HSCT, did not have independent prognostic value.

The risk of relapse after allo-HSCT as expected did not depend from the degree of pulmonary comorbidity. Despite this, due to significant differences in NRM, pulmonary comorbidity was associated with a decrease in overall survival: $71.9 \%$ (95\% CI, 63.8-78.5), 61.9\% (95\% CI, 42.5-76.4), 
Table 7. Multivariate analysis of characteristics affecting non-relapse mortality

\begin{tabular}{|l|l|l|l|l|}
\hline Parameter & HR & Lower 95\% Cl & Upper 95\% Cl & p \\
\hline $\begin{array}{l}\text { Severity of pulmonary function abnormalities } \\
\text { (HCT-CI criteria) 0 vs I vs 2 vs 3 }\end{array}$ & 1.3930 & 1.0270 & 1.8890 & 0.033 \\
\hline Diagnosis (SAA vs AML/ALL vs Lymphomas vs MPD/MDS) & 1.4040 & 1.0490 & 1.8790 & 0.023 \\
\hline Pretransplant disease status (CR vs non-CR) & 2.5710 & 1.5590 & 4.2400 & 0.0002 \\
\hline Conditioning (RIC vs MAC) & 1.9740 & 1.1280 & 3.4550 & 0.017 \\
\hline Type of donor (MRD vs MUD vs Haplo) & 4.0450 & 2.0960 & 7.8060 & 0.00003 \\
\hline Year of HSCT (22015 vs <2015) & 0.3875 & 0.2019 & 0.7438 & 0.004 \\
\hline Severe aGVHD (No vs Yes) & 2.3260 & 1.0800 & 5.0090 & 0.031 \\
\hline
\end{tabular}

Abbreviations: HR, hazard ratio; CI, confidential interval; SAA, severe aplastic anemia; AML, acute myeloid leukemia; ALL, acute lymphoblastic leukemia; MPD, myeloproliferative disorder; MDS, myelodysplastic syndrome; $C R$, complete response; MAC, myeloablative conditioning; RIC, reduced intensity conditioning; MRD, matched related donor; MUD, matched unrelated donor; Haplo, haploidentical donor; aGVHD, acute graft-versus-host disease.

$54.3 \%$ (95\% CI, 36.2-69.1) and 39.0 (95\% CI, 14.3-63.3) at 5 years after allo-HSCT with $0,1,2$, and 3 degrees respectively ( $\mathrm{p}=0.0014)$ (Fig. 3).

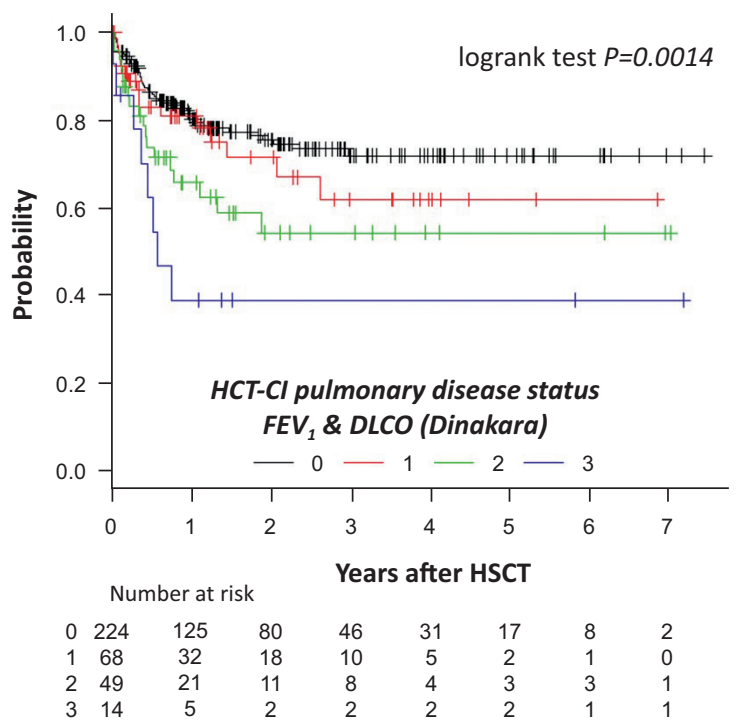

Figure 3. Overall survival after allo-HSCT with stratification of patients according to the severity of pulmonary comorbidity

\section{Discussion}

The HCT-CI is an important diagnostic tool in screening candidates for allo-HSCT $[8,9,17]$. Despite some inaccuracies with HCT-CI as prognostic indicators, a score of 3 and above always remains a sign of a high-degree risk for relapse-unrelated deaths. Currently, the assessment of the bronchopulmonary condition is one of essential components in pre-transplant examination of the patients, including PFTs with FEV1 and DLco, assessment, as well as chest CT evaluation [19].

The study by M. Sorror and colleagues has revealed that FEV1 and/or DLco reflect a correlation between causes of death and pulmonary comorbid pathology when assessing NRM rates [8]. Of the 347 patients who had moderate or severe degrees of pulmonary comorbidity, 122 died from causes unrelated to the relapse of primary disease. The causes of NRM were severe pulmonary toxicity (24\%), pulmonary complications of cGVHD (11\%), lower respiratory tract infections ( $45 \%)$ that were associated (18\%), or non-associated (27\%) with cGVHD, and other causes (20\%) [8].

Conventional spirometry is the most common screening method in examining the function of respiratory system. Spirometry is aimed to identify and determine the type of pulmonary function disorders, primarily obstructive, with the Tiffeneau index and FEV1 $[20,21]$. Spirometry makes it possible to diagnose broncho-obstructive diseases (BA, COPD, etc.), like as to predict clinical outcomes of the scheduled allo-HSCT $[9,19]$.

The DLco test is another functional method for assessing the state of lower respiratory tract. It is used to evaluate gas exchange via the alveolar-capillary membrane [20,21]. The DLco test detects probable interstitial changes of pulmonary tissue in patients with a history of using pulmonary toxic drugs (cytarabine, bleomycin, carmustine, nivolumab, etc.), radiation therapy, as well as changes associated with the course of the underlying disease (specific pulmonary tissue involvement, iron overload, etc.) [20-27].

Despite its obvious diagnostic advantage in identifying "subclinical" pulmonary injuries associated with the course or therapy of oncohematological disease, the DLco study is technically difficult for real clinical practice, thus being rarely performed in routine functional diagnostics.

The main objective of this study was to perform comprehensive analysis of lung health before allo-HSCT, and its connection with development of infectious and non-infectious bronchopulmonary complications in the post-transplant period, as well as NRM rates. Our analysis included 355 adult patients with various neoplastic and benign blood diseases who received allo-HSCT from a related, unrelated, and haploidentical donors. In contrast to previously published data, the analyzed cohort was balanced in terms of conditioning 
regimen (MAC 40\%, RIC 60\%) and graft source (BM 38\%, G-PBSC 62\%) [8-11]. Median age of the patients at the time of allo-HSCT (33 years old) was lower compared with other observations, but the distribution of primary diagnoses did not significantly differ $[8,10,11]$. For the first time, adult patients with SAA (8\%) were presented in the cohort.

The study assessed anamnestic data on pre-existing chronic respiratory diseases (COPD, BA) and previous bronchopulmonary infections (pneumonia, invasive mycosis, TBC). In addition, the presence of risk factors for the development of bronchopulmonary diseases (smoking, chemotherapy with pulmonary toxic drugs, mediastinal radiation therapy) was taken into account. In the observed cohort, COPD and BA were documented in $4.2 \%$ and $1.1 \%$ of patients, respectively, which is significantly lower than the data of the largest international and Russian population-based studies concerning general prevalence of COPD and BA (11.7\% and 6.9\%) [28]. According to literature data, the prevalence of COPD and BA among HSCT recipients was $2 \%$ and $12.2 \%[8,29]$. This fact can be explained by the negative selection of patients with severe forms of disease at earlier stages of treatment, even before their admission to the HSCT center.

A third of patients had a history of smoking, but a high smoking index was only $8 \%$ of patients from the entire cohort, which is comparable with another study, where the incidence of high smoking experience was 14\% [30]. Pulmonary infections before allo-HSCT were in $44.9 \%$ of patients, among which pneumonia (35.8\%), invasive mycosis (16\%) and TBC (2.8\%) prevailed. These data are similar to the results previously published by our group [31]. History of potential pulmonary toxic chemotherapy was documented in $72 \%$ of patients. However, no cases of drug-induced interstitial lung disease (DIILD) were detected in the analyzed cohort. According to available literature, the frequency of cytarabine-related DIILD varies from 15 to $44 \%$, whereas for bleomycin, this condition is found in $6.8-21 \%$ of the patients [32-36]. The novel form of DIILD caused by nivolumab may be as frequent as in $11.7 \%$ of cases [37].

Pulmonary changes according to chest CT before allo-HSCT were detected in $71 \%$ of patients, including signs of local pulmonary fibrosis (58\%) and focal changes (38\%). An earlier study detected CT changes in $48 \%$ of patients with AML, ALL, and MDS before allo-HSCT [38]. Unlike our data, the foci in pulmonary tissue (46\%) and ground-glass opacities (17\%) were the most frequent CT symptoms. CT signs of terminal bronchiolitis, cavities and pleural effusion have also been detected relatively rarely.

Analysis of PFT parameters was carried out in the entire cohort of patients, as well as in groups of patients with different hematological disorders. Based on the HCT-CI criteria, we analyzed patients with mild, moderate, and severe degrees of pulmonary comorbidity [8]. The median FEV1 (106\%) was higher than that shown in other multicenter studies, while the frequency of FEV1 decline was mild (14\%), moderate (9\%) and severe (2\%), which did not significantly differ from earlier literature data [10-11].

In the present study we compared two methods of DLco adjustment for hemoglobin level: the method proposed by
J.E. Cotes et al., recommended by ATS/ERS which is more commonly used in pulmonary practice, as well as the Dinakara method used by the Fred Hutchinson Cancer Research Center [15-18, 39-42]. According to our data, the Dinakara method seems to more precisely correct the impact of anemia to a decrease in DLco, which is comparable with similar results from another clinical study [42]. As a result, there was a decrease in DLco of mild (29\%), moderate (28\%) and severe $(12 \%)$ degrees, which is comparable with the reported results of other observations [10-11].

Analysis of PFT parameters in patients with various hematological diseases revealed a decrease in the Tiffeneau index in patients with MPD and MDS, as well as a reduced DLco in patients with lymphomas. This relationship is not described in the literature, which is probably due to the previously low transplant activity in these groups of patients. It can be assumed that these disease-specific relationships are caused by the age of the patients, the history of pulmonary toxicity and radiation therapy, the length of smoking and proven COPD.

The key result of the study was a strong confirmation of the high prognostic significance of pulmonary comorbidity for allo-HSCT outcomes in the real-world practice and in context of changing transplant landscape $[8,10]$. The patients with moderate and severe pulmonary comorbidity showed a 2- 3 fold increase in the cumulative incidence of MV requirements in the early post-transplant period. At the same time, the risk of NRM increased 2-4 times if compared to the patients without documented pulmonary comorbidity. Despite lacking differences in the frequency of relapses of the underlying disease, an association was found between moderate and, especially, severe degrees of pulmonary comorbidity and a decrease in overall survival.

Our study had a number of limitations, in particular, incomplete coverage of the cohort with DLco testing data in retrospective phase, which could cause underestimation of pulmonary comorbidity. However, taking into account the above-described features of a cohort based on the representation of different diagnoses, donor types, transplant sources, conditioning regimens and GVHD prophylaxis, the independent prognostic value of pulmonary comorbidity, as confirmed by multivariate analysis, is of particular importance.

\section{Conclusion}

Adult recipients of allogeneic HSCs have a wide range of potential causes and a high incidence of pulmonary comorbidity: non-infectious (5\%) and infectious (45\%) lung diseases, history of potential pulmonary toxicity (72\%), lung changes according to CT (70\%), disorders of respiratory function according to FEV1 (25\%) and aDLco (69\%). Pulmonary comorbidity and the frequency of violations of respiratory function have some disease-specific features.

In real practice, the use of a screening level of the PFT (spirometry) underestimates or incorrectly assesses the frequency of respiratory disorders in patients before allo-HSCT. The traditional DLco correction for hemoglobin level according to the Cotes method does not accurately reflect the 
contribution of anemia to impaired pulmonary diffusion capacity in adult patients with blood diseases and leads to an overestimated frequency of detecting severe violations of respiratory function before allo-HSCT. The Dinakara method provides more accurate DLco correction for hemoglobin levels.

In the modern landscape of allo-HSCT with a changing spectrum of indications, age of patients, conditioning regimens, GVHD prophylaxis, the degree of pulmonary comorbidity according to HCT-CI still retains a high predictive value in terms of risk of the MV and NRM.

\section{Conflict of interest}

The authors report no conflicts of interest.

\section{References}

1. Afanasyev BV, Zubarovskaya LS, Moiseev IS. Allogeneic hematopoietic stem cell transplantation in children: now, problems and prospects. Russian J Pediatric Hematol Oncol. 2015;2(2):28-42. (In Russian).

2. Savchenko VG, Liubimova LS, Parovichnikova EN, Mendeleeva LP, Mamotiuk KS, Demidova IA, Gribanova EO, Gal'tseva IV, Pokrovskaia OS, Kuz'mina LA, Zhelnova EI, Kliasova GA, Glasko EN, Kaplanskaia IB, Poreshina LP, et al. Transplantations of allogenic and autologous hemopoietic stem cells in acute leukemia (results of 20-year experience). Terapevticheskiy arkhiv. 2007;79 (7):30-35. (In Russian).

3. Rumyantsev AG, Maschan AA Hematopoietic stem cell transplantation in children. M.: Medical Information Agency, 2003. 909 pp. (In Russian.)

4. Duarte RF, Labopin M, Bader P, Basak GW, Bonini C, Chabannon C, Corbacioglu S, Dreger P, Dufour C, Gennery AR, Kuball J, Lankester AC, Lanza F, Montoto S, Nagler A, de Latour RP, Snowden JA, Styczynski J, Yakoub-Agha I, Kröger N, Mohty M for the European Society for Blood and Marrow Transplantation (EBMT). Indications for haematopoietic stem cell transplantation for haematological diseases, solid tumours and immune disorders: current practice in Europe, 2019. Bone Marrow Transplant. 2019:1-28. Published: 05 April 2019. doi.org/10.1038/s41409-019-0516-2.

5. Gooley TA, Chien JW, Pergam SA, Hingorani S, Sorror ML, Boeckh M, Martin PJ, Sandmaier BM, Marr KA, Appelbaum FR, Storb R, McDonald GB. Reduced mortality after allogeneic hematopoietic-cell transplantation. N Engl J Med. 2010;363(22):2091-2101.

6. Horan JT, Logan BR, Agovi-Johnson M-A, Lazarus HM, Bacigalupo AA, Ballen KK, Bredeson CN, Carabasi $\mathrm{MH}$, Gupta V, Hale GA, Khoury HJ, Juckett MB, Litzow MR, Martino R, McCarthy PL, Smith FO, Rizzo JD, Pasquini MC. Reducing the risk for transplantation-related mortality after allogeneic hematopoietic cell transplantation: how much progress has been made? J Clin Oncol. 2011;29(7):806-813.

7. Charlson ME, Pompei P, Ales KL, MacKenzie CR. A new method of classifying prognostic comorbidity in longitudinal studies: development and validation. J Chronic Dis. 1987;40(5):373-383.
8. Sorror ML, Maris MB, Storb RF, Sandmaier MB, Maloney DG, Storrer B. Hematopoietic cell transplantation (HCT)-specific comorbidity index: a new tool for risk assessment before allogeneic HCT. Blood. 2005;106(8):2912-2919.

9. Sorror ML, Storb RF, Sandmaier BM, Maziarz RT, Pulsipher MA, Maris MB, Bhatia S, Ostronoff F, Deeg MH, Syrjala KL, Estey E, Maloney DG, Appelbaum FR, Martin PJ, Storer BE. Comorbidity-age index: a clinical measure of biologic age before allogeneic hematopoietic cell transplantation. J Clin Oncol. 2014;32(29):3249-3256.

10. Parimon T, Madtes DK, Au DH, Clark JG, Chien JW. Pretransplant lung function, respiratory failure, and mortality after stem cell transplantation. Am J Respir Crit Care Med. 2005;172(3):384-390.

11. Piñana JL, Martino L, Barba P, Bellido-Cassado J, Valcarcel D, Sureda A, Briones J, Brunet S, Rodriguez-Arias JM, Casan P, Sierra J. Pulmonary function testing prior to reduced intensity conditioning allogeneic stem cell transplantation in an unselected patient cohort predicts posttransplantation pulmonary complications and outcome. Am J Hematol. 2012;87(1):9-14.

12. Dobronravov VA, Smirnov KA, Afanasiev BV, Galkina OV, Smirnov AV. Subclinical tubular epithelium damage and acute kidney injury following allogeneic hematopoietic stem cell transplantation. Cell Ther Transplant. 2016; 5(4):8-14.

13. Roziakova L, Mistrik M, Batorova A, Kruzliak P, Bojtarova E, Dubrava J, Gergel J, Mladosievicova B. Can we predict clinical cardiotoxicity with cardiac biomarkers in patients after haematopoietic stem cell transplantation? Cardiovasc Toxicol. 2015;15(3):210-216.

14. Wu AC, Kiley JP, Noel PJ, Amur S, Burghard EG, Clancy JP, Galanter J, Inada M, Jones TK, Kropski JA, Loyd JE, Nogee LM, Raby BA, Rogers AJ, Schwartz DA, Sin DD, Spira A, Weiss ST, Young LR, Himes BE. Current status and future opportunities in lung precision medicine research with a focus on biomarkers. An American Thoracic Society/National Heart, Lung, and Blood Institute Research Statement. Am J Respir Crit Care Med. 2018;198(12):116-136.

15. Pellegrino R, Viegi G, Brusasco V, Crapo RO, Burgos F, Casaburi R, Coates A, van der Grinten CPM, Gustafsson P, Hankinson J, Jensen R, Johnson DC, MacIntyre M, McKay R, Miller MR, Navajas D, Pedersen OF, Wanger J. Interpretive strategies for lung function tests. Eur Respir J. 2005;26(5):948-968.

16. Cotes J. E. Measurement of the transfer factor (diffusing capacity) for the lung and its subdivisions. Lung function assessment application in medicine. 4th ed. Oxford, UK: Blackwell Scientific Publications. 1979:230-250.

17. Dinakara P, Blumenthal WS, Johnston RF, Kauffman LA, Solnick PB. The effect of anemia on pulmonary diffusing capacity with derivation of a correction equation. Am Rev Respir Dis. 1970:102(6):965-969.

18. Clement RF. Fundamental and methodological foundations for the development of a unified system of proper quantities. Current problems of clinical respiratory physiology. 1987:5-19. (In Russian). 
19. Carreras E, Dufor C, Mohty M, Kröger N. The EBMT Handbook: Hematopoietic Stem Cell Transplantation and Cellular Therapies. Springer. 2019:77-86.

20. Chuchalin AG. Pulmonology. National guidelines. Moscow: GEOTAR-Media. 2012: 117-135. (In Russian).

21. Savushkina OI, Chernyak AV. Pulmonary functional tests: from theory to practice. A guide for doctors. Moscow: Strom. 2017:11-38; 63-82. (In Russian).

22. Skeoch S, Weatherley N, Swift AJ, Oldroyd A, Johns C, Hayton C, Giollo A, Wild JM, Waterton JC, Buch M, Linton K, Bruce IN, Leonard C, Bianchi S, Chaudhuri N. Drug-induced interstitial lung disease: a systematic review. J Clin Med. 2018;7(10):1-30.

23. DeMonaco NA, McCarty Jr KS, Joyce J, Jacobs SA. Focal radiation fibrosis after radioimmunotherapy for follicular non-Hodgkin lymphoma. Clin Lymphoma Myeloma. 2007;7(5):369-372.

24. Guner SI, Yanmaz MT, Selvi A, Usul C. Chemotherapy and radiation induced pulmonary dysfunction in Hodgkin lymphoma patients. Indian J Hematol Blood Transfus. 2016;32(4):431-436.

25. Berkman N, Breuer R, Kramer MR, Polliack A. Pulmonary involvement in lymphoma. Leuk Lymphoma. 1996;20(3-4):229-237.

26. Mian M, Wasle I, Gritsch S, Willenbacher W, Fiegl M. B cell lymphoma with lung involvement: what is it about? Acta Haematol. 2015;133(2):221-225.

27. Kamble R, Rosenzweig T. Diffuse pulmonary parenchymal involvement in multiple myeloma: antemortem diagnosis. Int J Hematol. 2006;83(3):259-261.

28. Global Initiative for Asthma. Global Strategy for Asthma Management and Prevention. 2017 update. 2017:13-24. Available at: http://www.ginasthma.org. Accessed June 23, 2017.

29. Chien SH, Liu C-J, Hong Y-C, Teng C-J, Hu Y-W, Shen C-C, Ku F-C, Chen S-C, Yeh C-M, Chiou T-J, Gau J-P, Tzeng C-H. Use of azathioprine for graft-vs-host disease is the major risk for development of secondary malignancies after haematopoietic stem cell transplantation: a nationwide population-based study. Br J Cancer. 2015;112(1):177-184.

30. Mehdi A, Rybicki L, Mossad S, Yurch M, Sekeres M, Gerds AT, Jagadeesh D, Hamilton B, Liu H, Dean R, Pohlman B, Sobecks R, Andresen S, Kalaycio M, Bolwell BJ, Majhail MS, Copelan E, Hill BT. Impact of cigarette smoking on survival after myeloablative allogeneic hematopoietic stem cell transplantation and contribution of invasive fungal infection. Bone Marrow Transplant. 2017;52(12);1665-1667.

31. Popova MO, Ekushov KA, Ayzsilnieks OV, Volkova AG, Pinegina ON, Ignatieva SM, Slesarchuk OA, Vladovskaya MD, Bondarenko SN, Zubarovskaya LS, Klimko NN, Afanasyev BV. Invasive fungal infections in recipients of allogeneic hematopoietic stem cell teens and young adults. Russian J Pediatric Hematol Oncol. 2016; (1):44-51. (In Russian).
32. Ilkovich MM. Interstitial and orphan lung diseases. Moscow: GEOTAR-Media. 2016:289-316 (In Russian).

33. Blum RH, Carter SK, Agre K. A clinical review of bleomycin - a new antineoplastic agent. Cancer. 1973;31(4):903914.

34. Hubbard SP, Chabner BA, Canellos GP, Young RC, DeVita Jr. VT. High dose intravenous bleomycin in the treatment of advanced lymphomas. Eur J Cancer. 1975;11(9):623-626.

35. Ngeow J, Tan IB, Kanesvaran R, Tan HC, Tao M, Quek R, Lim ST. Prognostic impact of bleomycin-induced pneumonitis on the outcome of Hodgkin's lymphoma. Ann Hematol. 2011;90(1):67-72.

36. Stamatoullas A, Brice P, Bouabdallah R, Mareschal S, Camus V, Rahal I, Franchi P, Lanic H, Tilly H. Outcome of patients older than 60 years with classical Hodgkin lymphoma treated with front line ABVD chemotherapy: frequent pulmonary events suggest limiting the use of bleomycin in the elderly. Br J Haematol. 2015;170(2):179-184.

37. Nishino M, Ramaiya NH, Awad MM, Sholl LM, Maattala JA, Taibi M, Hatabu H, Ott PA, Armand PF, Hodi FS. PD-1 inhibitor-related pneumonitis in advanced cancer patients: radiographic patterns and clinical course. Clin Cancer Res. 2016;22(24):6051-6060.

38. El Boghdadly Z, Oran B, Rondon JG, Champlin R, Kontoiyannis DP. Pretransplant chest computed tomography screening in asymptomatic patients with leukemia and myelodysplastic syndrome. Bone Marrow Transplant. 2017;52(3):476-479.

39. Sorror ML. How I assess comorbidities before hematopoietic cell transplantation. Blood. 2013;121(15):2854-2863.

40. Armand P, Kim HT, Logan BR, Wang Z, Alyea EP, Kalaycio ME, Maziarz RT, Antin JH, Soiffer RJ, Weisdorf DJ, Rizzo D, Horowitz MM, Saber W. Validation and refinement of the Disease Risk Index for allogeneic stem cell transplantation. Blood. 2014;123(23):3664-3671.

41. Shouval R, Labopin M, Bondi O, Mishan Shamay H, Shimoni A, Ciceri F, Esteve Reiner J, Giebel S, Gorin NC, Schmid C, Polge E, Aljurf M, Kroger N, Craddock CF, Bacigalupo A, Cornelissen JJ, Baron F, Under R, Nagler A, Mohty M. Prediction of allogeneic hematopoietic stem-cell transplantation mortality 100 days after transplantation using a machine learning algorithm: a European Group for Blood and Marrow Transplantation Acute Leukemia Working Party Retrospective Data Mining Study. J Clin Oncol. 2015;33(28):3144-3151.

42. Coffey DG, Pollyea DA, Myint H, Smith C, Gutman JA. Adjusting DLCO for $\mathrm{Hb}$ and its effects on the Hematopoietic Cell Transplantation-specific Comorbidity Index. Bone Marrow Transplant. 2013;48(9):1253-1256. 


\title{
Характеристика и прогностическое значение функцио- нальных нарушений и коморбидной патологии легких у взрослых пациентов при проведении аллогенной трансплантации гемопоэтических стволовых клеток
}

\author{
Егор А. Кулагин ${ }^{1}$, Алиса Г. Волкова ${ }^{2}$, Илья Ю. Николаев ${ }^{2}$, Олег В. Голощапов ${ }^{2}$, Анна Г. Смирнова ${ }^{2}$, \\ Татьяна А. Рудакова ${ }^{2}$, Елена И. Дарская ${ }^{2}$, Елена В. Морозова ${ }^{2}$, Наталья Б. Михайлова ${ }^{2}$, Юлия Д. Рабик ${ }^{3}$, \\ Виктория Г. Тимчик ${ }^{3}$, Татьяна И. Щемелинина ${ }^{3}$, Руфь Д. Скворцова ${ }^{3}$, Татьяна С. Разумовская ${ }^{3}$, \\ Сергей Н. Бондаренко ${ }^{2}$, Иван С. Моисеев ${ }^{2}$, Валерий Н. Марченко ${ }^{1}$, Василий И. Трофимов ${ }^{1}$, Борис В. Афанасьев ${ }^{2}$ \\ ${ }^{1}$ Кафедра госпитальной терапии с курсом аллергологии и иммунологии имени академика М.В. Черноруцкого, \\ Санкт-Петербург, Россия \\ ${ }^{2}$ НИИ детской онкологии, гематологии и трансплантологии им. Р. М. Горбачевой, Санкт-Петербург, Россия \\ ${ }^{3}$ Отделение функциональной диагностики №2 Научно-клинического исследовательского центра, \\ ФГБОУ ВО «Первый Санкт-Петербургский государственный медицинский университет им. акад. И. П. Павлова» \\ Минздрава России, Санкт-Петербург, Россия
}

\section{Резюме}

Высокая эффективность аллогенной трансплантации гемопоэтических стволовых клеток (аллоТГСК) при широком спектре злокачественных и незлокачественных заболеваний системы крови ограничивается риском тяжелых осложнений и летального исхода без признаков рецидива или прогрессирования основного заболевания (безрецидивная летальность). Среди ключевых факторов безрецидивной летальности рассматривается коморбидность до момента алло-ТГСК. Целью настоящего исследования было охарактеризовать потенциальные предтрансплантационные факторы легочной коморбидности и интегральные показатели функции внешнего дыхания (ФВД) и оценить их прогностическое значение для исходов алло-ТГСК у взрослых пациентов.

\section{Пациенты и методы}

Исследование включало 355 больных, в том числе 149 (42\%) в проспективной фазе исследования. Сформированная когорта включала пациентов с острыми лейкозами (60\%), миелопролиферативными заболеваниями (10\%), миелодиспластическим синдромом (5\%), лимфомами (17\%) и тяжелой апластической анемией (8\%). Медиана возраста на момент аллоТГСК составила 33 года (18-66). Анализировались все потенциальные предтрансплантационные факторы легочной компрометации. Степень тяжести легочной коморбидности оценивалась на основании параметров ФВД - объема форсированного выдоха за первую секунду (ОФВ1) и диффузионной способности лёгких для оксида углерода (CO) (DLco) в соответствии с критериями индекса коморбидности Hematopoietic cell transplantation specific comorbidity index (НСТ-CI). Прогностическое значение степени легочной коморбидности исследовано в отношении кумулятивной частоты перевода на искусственную вентиляцию легких (ИВЛ) и безрецидивной летальности.

\section{Результаты}

Среди наиболее частых факторов легочной компрометации до алло-ТГСК идентифицированы курение (32\%), анамнез хронической обструктивной болезни легких (ХОБЛ) и бронхиальной астмы (БА) (5\%), инфекции легких (45\%), потенциально пульмонотоксичная химиотерапия (79\%), аутологичная ТГСК (8\%), ингибиторы иммунных контрольных точек (5\%), лучевая терапия на область средостения (6\%) и др. Критериальное снижение ОФВ1 от должного имело место у 90 (25\%) больных, включая 14\%, 9\% и $2 \%$ легкой, средней и тяжелой степени соответственно. Нарушение DLco было выявлено у 69\% обследованных пациентов, включая 29\%, 28\% и 12\% легкой, средней и тяжелой степени соответственно. Кумулятивная частота перевода на ИВЛ в течение 100 дней после алло-ТГСК составила 7,2\%, 10,9\%, 16,7\% и $22,1 \%$ у пациентов с легочной коморбидностью 0 , $1,2,3$ степени соответственно. Степень легочной коморбидности была независимым фактором риска безрецидивной летальности (отношение рисков 1,39, ДИ 95\%, 1.03-1.89, p=0.033) и ассоциировалась со снижением общей выживаемости.

\section{Выводы}

Взрослые пациенты имеют широкий спектр факторов легочной коморбидности до алло-ТГСК. Легочная коморбидность по НСТ-СI является фактором риска перевода на ИВЛ в течение первых 100 дней после алло-ТГСК и безрецидивной летальности.

\section{Ключевые слова}

Аллогенная трансплантация гемопоэтических стволовых клеток, взрослые, коморбидная патология легких, функция внешнего дыхания, клинический прогноз. 